\title{
Osteotomy and grafting of the distal radius using virtual planning and patient specific guides
}

Stephen Kemp

From 10th Congress of the Asia-Pacific Federation of Societies of Surgery fo the Hand and the 6th Congress of Asia-Pacific Federation of Societies of Hand Therapists

Kuala Lumpur, Malaysia. 2-4 October 2014

Corrective osteotomy of the distal radius for malunion has always been a challenging procedure. Deformity involves length, angulation and rotation. Planning an osteotomy on plain $\mathrm{x}$-rays is difficult and in-exact. Reproducing that planned osteotomy in the operating theatre is even more difficult.

Attempts to improve accuracy with the use of CT scanning and even the production of models have met with varying success. More recently however, software
(Materialise N.V, Belgium) has been developed which allows the generation of virtual 3-D models of the bones of both forearms from a CT scan following a specific protocol. These models can be manipulated in a virtual environment. The contralateral model can be mirrored and superimposed on the malunion. Following a virtual osteotomy the fragment of the malunited radius can be manoeuvred into a desired post-operative position using the normal radius as a template for correction. Virtual

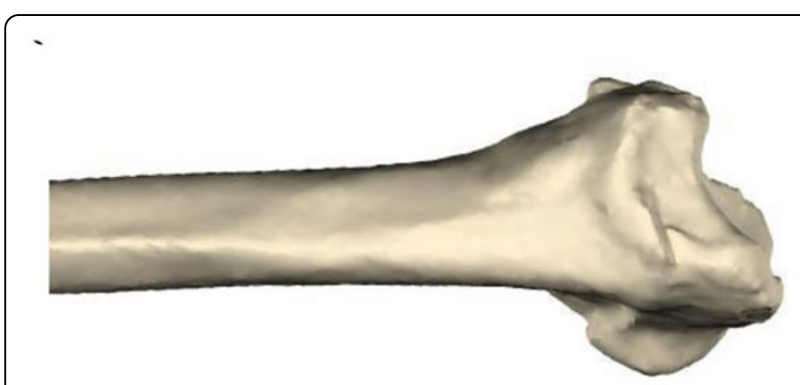

Virtual model of pre-operative radius

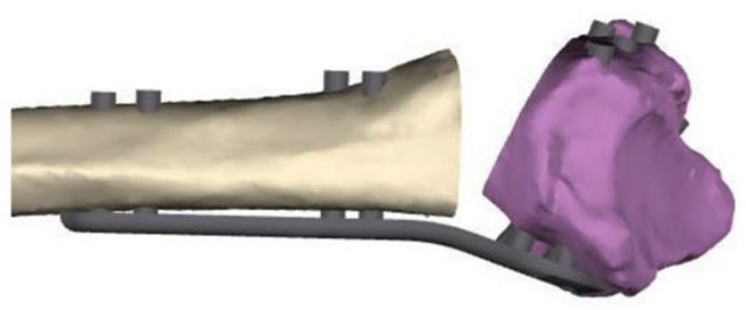

Virtual planned correction of the radius

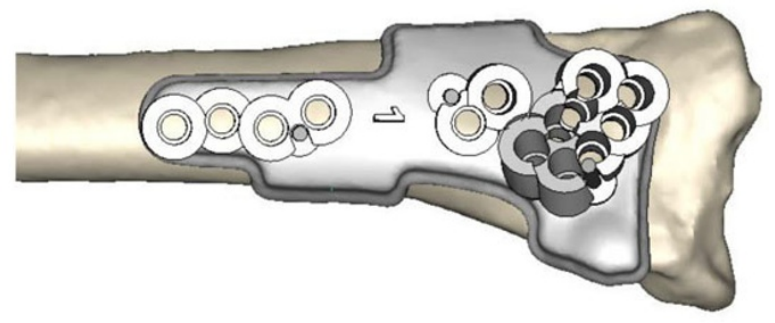

Patient specific drill guide on virtual preoperative radius

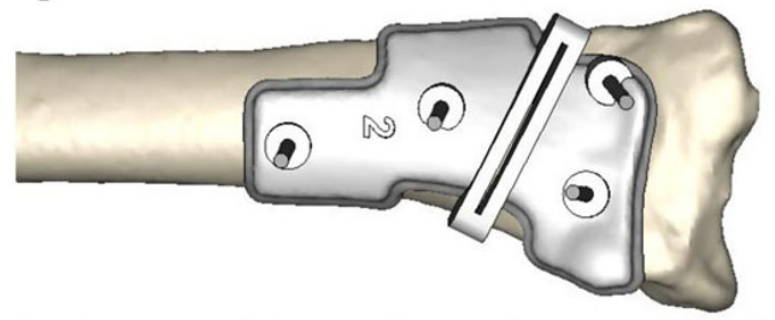

Patient specific cutting guide on virtual pre-operative radius

Figure 1

Hunter Hand and Upper Limb Surgery, New South Wales, Australia

(c) 2015 Kemp; licensee BioMed Central Ltd. This is an Open Access article distributed under the terms of the Creative Commons Attribution License (http://creativecommons.org/licenses/by/4.0), which permits unrestricted use, distribution, and reproduction in any medium, provided the original work is properly cited. The Creative Commons Public Domain Dedication waiver (http:// 
models of a specific plate and corresponding screws can be fitted into the best position.

Reverse engineering this virtual plan allows a series of patient specific guides to be designed and produced using additive manufacturing technology. All the screw holes can be drilled first followed by the osteotomy. The soft tissues are released as necessary and the plate applied.

In comparison to experiences with similar cases done conventionally, the observed accuracy of the surgery is quite astounding. The correction is achieved to within millimetre tolerance. Operative time is reduced. The real strength of this approach is its versatility. The surgeon can sit down with an engineer over the internet and actively participate in the planning of each surgery. In simple corrections this can be straightforward, however more significant corrections require careful assessment and a flexible approach.

The technology will be presented from a surgeon's perspective and three cases used to highlight the versatility of the approach.

Published: 19 May 2015

doi:10.1186/1753-6561-9-S3-A96

Cite this article as: Kemp: Osteotomy and grafting of the distal radius using virtual planning and patient specific guides. BMC Proceedings 2015 9(Suppl 3):A96
Submit your next manuscript to BioMed Central and take full advantage of:

- Convenient online submission

- Thorough peer review

- No space constraints or color figure charges

- Immediate publication on acceptance

- Inclusion in PubMed, CAS, Scopus and Google Scholar

- Research which is freely available for redistribution

Submit your manuscript at www.biomedcentral.com/submit 